\title{
Insulin-like Growth Factors in a clinical setting: Review of IGF-I
}

\author{
Zdenek Frysak ${ }^{a}$, Jan Schovanek ${ }^{\mathrm{a}}$, Maurizio lacobone ${ }^{\mathrm{b}}$, David Karasek ${ }^{\mathrm{a}}$
}

\begin{abstract}
Background and Aims. Interest in growth hormone $(\mathrm{GH})$ is inextricably linked to the need for in depth understanding of the somatomedins (insulin-like growth factors) which are polypeptides structurally similar to insulin and with broad physiological activity. To date, the most commonly known is Insulin-Like Growth Factor I (IGF-I). Despite considerable current knowledge of IGF-I, however, its bioactivity is incompletely understood. Measurement of IGF-I is of the utmost importance in the diagnosis and treatment of, for example acromegaly and growth hormone deficiency. The development of recombinant IGF-I, has allowed its use in such cases. Clinical practice, however, shows that few young/adult patients will benefit from treatment with the rIGF-I, mecasermin, given the number of adverse effects found. This review focuses on current knowledge mainly related to IGF-I and the use of its recombinant form (rIGF-I) in clinical practice. Several functions of IGI-II have been elucidated but their clinical significance is unclear.
\end{abstract}

Key words: Somatomedins, Insulin-Like Growth Factor I, II, IGF-I receptor, Human Growth Hormone, Recombinant Human Growth Hormone, Acid Labile Subunit, IGF Binding Proteins, Mecasermin, Insulin Receptor Isoform A, acromegaly, growth hormone deficiency

Received: April 28, 2015; Accepted with revision: July 28, 2015; Available online: September 2, 2015

http://dx.doi.org/10.5507/bp.2015.041

${ }^{a}$ Department of Internal Medicine III-Nephrology, Rheumatology and Endocrinology, University Hospital and Faculty of Medicine and Dentistry, Palacky University Olomouc, Czech Republic, I.P.Pavlova 6-779 00, - Olomouc, Czech Republic

${ }^{b}$ Minimally Invasive Endocrine Surgery Unit, Department of Surgery, Oncology and Gastroenterology, University of Padova, Italy, Via Giustiniani 2 - 35128 - Padova, Italy

Corresponding author: Zdenek Frysak, zdenek.frysak@gmail.com

\section{INTRODUCTION}

Somatomedins refer to a group of polypeptides, today commonly known as Insulin-like Growth Factors (IGFs) that participate in a plethora of cellular processes. Their first discovery is attributed to Salmon and Daughaday, who in 1957, reported that GH injected into rat cartilage in vivo facilitated incorporation of sulfate ("sulfation factor"). However, the same process could not be induced in cell cultures ${ }^{1}$. These authors thus indirectly proved the existence of the somatomedins. Research in recent decades has uncovered the molecular structure of IGF and a number of its functions. Detailed description of the molecular structure was followed by synthesis of recombinant IGF-I that has facilitated its use in clinical practice.

\section{Chemical structure and origin}

The somatomedin group includes IGF-I and IGF-II which are around 50\% identical to the amino acid precursor of insulin, proinsulin, the longest known structure of the three substances. IGF-I forms a single chain of 70 amino acids with three intermolecular disulfide bridges and a molecular weight of 7649 Daltons $^{2}$. Although similar in structure, the three polypeptides have very different origins. Insulin, proinsulin more precisely, is formed by pancreatic $\beta$-cells, its activation is preceded by cleavage of the C-peptide with a half-life time calculated in minutes and it affects mainly the metabolism of hepatocytes, myocytes and adipose tissue cells. Unlike IGFs, insulin production, excretion and activity are not influenced by
GH. These differences relate only marginally to our topic but they are reviewed by Rinderknecht et. $\mathrm{al}^{2}$. IGFs on the other hand, are formed in a far greater number of tissues and even today it is not possible to reliably identify which specific cells are responsible for their production. IGF-I (somatomedin C) and IGF-II mRNA can be detected by in situ hybridization histochemistry in the connective tissue of 14 organs (e.g. parasinusoidal liver cells, perichondrial cartilage, eye sclera, septa and connective tissue enveloping most organs) and also in human embryo tissues. Such cell structures are widely distributed in the human body. Thus, it is possible that IGFs are formed both locally and systemically, also creating the possibility of autocrine or paracrine effects ${ }^{3}$.

\section{Genetics}

Human genome studies have revealed two genes responsible for the production of IGFs. These exist as a single-copy gene. The largest amount of somatomedin mRNA is detected in the liver, as well as in the kidney, brain and myocardium. IGFs are released into circulation with subsequent binding to one of six IGF-binding proteins which modulate their activity. Binding proteins with affinity for IGF-I and IGF-II are locally produced in most tissues. A cDNA probe corresponding to mRNA encoding IGF-I was used for chromosomal assignment of the IGF-I gene. Interestingly, comparison of the chromosomal assignment of the IGF-I gene and two other members of the insulin gene family, with three c-ras oncogenes, revealed remarkable similarity of the two gene families. 
The human gene encoding human insulin-like growth factor was identified on chromosome $12\left(\right.$ ref. $\left.^{4}\right)$ as well as the proto-oncogene, $\mathrm{c}_{\mathrm{Ki}^{-}}$-ras $\left(\right.$ref. $\left.^{5}\right)$. Current knowledge suggests that IGF-I gene polymorphism affects human height, length of life and senses, such as sight and hearing ${ }^{6-9}$.

\section{Receptors for IGF}

GH produced by the pituitary has a stimulatory effect on expression of the IGF-I gene, leading to the formation of IGF-I polypeptide chain. Increase in IGF-I levels reversely suppresses $\mathrm{GH}$ pituitary production. Both IGF-I and IGF-II have high binding affinity specific for the two sites of tyrosine kinase receptors like insulin. Although the intracellular response is similar to the one induced by insulin, IGFs influence growth and differentiation processes unlike insulin. IGFs reduce blood glucose levels but their effect is roughly about $5 \%$ of insulin's. Another important factor affecting their immediate activity is their binding protein (BP), allowing transport of IGFs to specific receptors in target tissues. For IGF-I this is primarily binding to IGF-I BP3.

Activation of the insulin-like growth factor-I receptor (IGF-IR) pathway has also been found to be involved in the initiation and growth of cancers. For this reason, the IGF-I receptor (IGF-IR) has been studied as an anticancer target. However, monotherapy trials with IGF-IR targeted anti bodies or IGF-IR specific tyrosine kinase inhibitors, have been overall very disappointing in the clinical setting. It has become clear that intracellular signaling pathways are highly interconnected and complex ${ }^{10}$. Nevertheless, it is still possible that IGF-IR targeted therapy may be useful as adjuvant or the secondary target treatment of human cancers. Unfortunately, IGF-IR targeted therapy might fail due to activation of insulin receptor isoform A (IR-A) by IGF-II and consequently bypassing inhibited IGF-IR ( ref. $^{11}$ ).

\section{Physiology of IGF-I}

The level of IGF-I production is influenced by many factors including gender and age. It is physiologically low at birth, with level increments in childhood and early adulthood, decreasing after 30 years of age. Production of IGF-I is stimulated by activated GH receptors; it has metabolic activities similar to those of insulin but also exerts its specific long term effects on cell proliferation and differentiation ${ }^{12-14}$. Low levels of circulating IGF-I are associated with reduced insulin sensitivity ${ }^{15}$ and increased risk of impaired glucose tolerance or type 2 diabetes development $^{16,17}$. A correlation has been found between IGF-I and cardiovascular mortality ${ }^{18}$.

In malnourished individuals, there is a decrease or even disappearance of $\mathrm{GH}$ receptor sensitivity affecting IGF-I production. A model situation is the psychological disorder; anorexia nervosa. GH and also in parallel, IGF-I decreases with the disease progression as an effect of starvation on receptor function ${ }^{19}$. This phenomenon includes hypothalamic amenorrhea, relative hypercortisolemia, reduced stimulated levels of leptin, insulin, amylin and incretins (glucagon-like polypeptide-1, glucose-dependent insulinotropic polypeptide), and conversely increased levels of adiponectin, ghrelin and peptide YY. Serious complications of anorexia nervosa include changes in bone microarchitecture with bone mineral density reduction, increased risk of fracture, neuro-cognitive impairment and the development of anxiety and depression. This could be seen as an indication for combined estrogen and IGF-I treatment in patients suffering from anorexia nervosa or those recovering from this condition ${ }^{19-22}$.

The opposite situation is the overproduction of $\mathrm{GH}$, with elevated IGF-I levels, in acromegaly. Although the relationship is not entirely linear, the normalization of IGF-I is considered as an essential indicator of activity, remission or cessation of the acromegalic process. Crucially important for maintaining the balance in the system of the circulating IGF/IGF-BP is ALS (acid-labile subunit). ALS is a critical component in the development of a large reservoir of IGFs by extending its half-life from $10 \mathrm{~min}$ of the free form to 30-90 min in binary complexes (early periods of human life), later to more than $12 \mathrm{~h}$, when bound into tertiary complexes ${ }^{23-25}$. Patients lacking ALS have significantly reduced serum IGF-I and IGFBP-3 leading to moderate growth retardation (height SDS -2 to -3 SDS before and during puberty). Twenty one male patients were described as lacking ALS as a result of 16 unique homozygous or compound heterozygous inactivating mutations of the IGF ALS gene. These boys had delayed puberty and varying degrees of insulin resistance. In the assessment of a short stature child, ALS deficiency should be considered in those presenting with a normal response to GH stimulation test, low IGF-I levels associated with more profoundly reduced IGFBP-3 levels, a mild growth retardation (apparently out of proportion to the degree of IGF-I and IGFBP-3 deficits), lack of response to IGF generation test and insulin insensitivity ${ }^{26}$.

\section{Methods of IGF-I measurement}

There are a number of commercially available immunoassay kits for measuring IGF-I as well as GH and IGFBP-3 using IRMA, RIA and ELISA methods. Several assays have traditionally been used to measure IGF-I bioactivity but have not become routine in laboratory practice owing to technical problems and high costs. Thus, there is still a need for rapid, technically simple and accurate assay to determine IGF-I bioactivity ${ }^{27}$. The main problem is standardization of methods regarding the issue of interference with IGF-I binding proteins, causing inaccurate and therefore unreliable results ${ }^{28}$. The binding proteins can be removed by acid gel filtration chromatography ${ }^{29}$. This procedure is however laborious and expensive. Hence, commercial laboratories do not use it, preferring acid displacement of binding proteins and then precipitated with ethanol in the investigated material. For a valid assay, only IGF-I should remain in the sample ${ }^{28}$. The incomplete removal of small molecules of binding proteins primarily not bound to ALS causes measurement errors. Recently, commercial immunoassays for IGF-I based on competitive non-sandwich approach methods have become available. Use of two antibodies, 
refines the result and the system allows for automated sample processing but the methodology is still based on acid/ethanol precipitation or the addition of IGF-II as a precaution against the interfering effects of the remaining binding proteins ${ }^{29}$. Overall, there are difficulties in results comparison between commercial IGF-I assays due to lack of standardization. This aside, IGF-I corrected for patient age is a basic laboratory marker in the differential diagnosis of conditions associated with excess, deficiency of or resistance to $\mathrm{GH}$.

\section{Dual use of IGF-I measurement in clinical practice}

Firstly, IGF-I has acquired an irreplaceable position in the diagnosis of acromegaly and gigantism. Suspicion of the process is based on the presence of clinical symptoms, detailed elsewhere in the literature ${ }^{30,31}$. Increased levels of IGF-I predicates active disease. If a randomly taken sample has a $\mathrm{GH}$ level below $1.0 \mathrm{ng} / \mathrm{mL}$, active process can be practically excluded. Diagnosis is confirmed unequivocally by a modified oral glucose tolerance test $(100,0 \mathrm{~g}$ glucose) with GH level monitoring every half hour for the following 2 or 3 hours, in case that, after the glucose load, the $\mathrm{GH}$ level does not decrease below $0.4 \mathrm{ng} / \mathrm{mL}$ (ref. ${ }^{30}$ ). Initial check of IGF-I combined with three independent samples of GH serum levels are generally accepted parameters of active acromegaly and gigantism ${ }^{31}$. Administration of somatostatin analogs has significantly expanded the options for acromegaly treatment with regular checks of IGF-I levels as a reliable indicator of therapeutic response $^{32,33}$. Its importance has resulted in a consensual treatment protocol describing long-acting somatostatin analogue treatment before surgery for pituitary adenoma in patients with acromegaly in the Czech Republic (unpublished data).

Secondly, IGF-I corrected for patient's age is commonly used as an indicator for substitution effectiveness of recombinant human growth hormone ( $\mathrm{rhGH})$, both in pediatric patients, where the dose of rhGH (approximately $40 \mathrm{mg} / \mathrm{kg}$ of body weight) is to ensure dynamic and optimal growth of a child patient. In adults, the applied schema and rhGH dosing meets specific requirements, as follows: in the case of men, the usual adult dosage ranges around $0.1-0.3 \mathrm{mg} / \mathrm{kg}$ of body weight. In woman without estrogen deficiency, a single evening dose could even double the male's dose. Lack of GH in adulthood as a single hormone deficiency must be suspected if IGF-I levels are below the age group standards ${ }^{34}$. Most patients with issues affecting the hypothalamic-pituitary axes are indicated for hormone evaluation testing. Patients at risk are those with a history of past surgery, radiotherapy or inflammatory brain process i.e. encephalitis ${ }^{35}$. The insulin tolerance test (ITT) in patients with low GH levels $(<3 \mu \mathrm{g} / \mathrm{L})$ is considered as a gold standard and as a test confirming the diagnosis of GH deficiency. If ITT is contraindicated (for unacceptable risk of hypoglycemia), there are other optional tests, e.g. an arginine test combined with an administration of single dose of GHRH (Growth hormone releasing hormone); L-Dopa and glucagon stimulation tests. The validity of the latter two stimulation tests, is however relative in the literature ${ }^{36}$. Clinical experience has confirmed that lack of 3 pituitary hormones other than $\mathrm{GH}$, implies with almost certainty also complete or at least significant $\mathrm{GH}$ deficiency ${ }^{20}$.

\section{IGF-I as a Therapeutic Agent}

In severe primary IGF-I deficiency, the unresponsiveness of hepatic $\mathrm{GH}$ receptors to normal $\mathrm{GH}$ stimulation, leads to reduced levels of endogenous IGF-I and consequently decreased growth (cells, skeleton, and organs). Mecasermin therapy - an insulin-like growth factor produced by recombinant DNA technology (rIGF-I) - might be the key to replace lack of endogenous IGF-I (ref. ${ }^{37}$ ). Endogenous IGF-I suppresses liver glucose production, stimulates peripheral glucose utilization and has an inhibitory effect on insulin secretion. The wide spectrum of its activities and biological effects on many different tissues holds promise for its use in a wide range of indications e.g. osteoporosis, diabetes mellitus and insulin resistance, GH insensitivity, obesity, various catabolic states and also possibly for some neuromuscular disorders. A typical representative is the Laron syndrome described in a number of studies. This includes postnatal growth failure, moderate to severe bone age delay relative to chronological age, short limb length in relation to trunk and delayed puberty by 3 to 7 years. Intellectual development is normal or modestly impaired. Morphological changes can be present in the head, neck and face region. Slower than normal is dentition and patients have a blue sclera. Sexual function and fertility are normal. They suffer from disorders of lipid metabolism and insulin resistance. Children of any age group develop osteopenia and are prone to hypoglycemia with metabolic obesity ${ }^{38-40}$.

Another indication for rIGF-I use appears to be insulin resistance, insulin-dependent diabetes mellitus and currently also non-insulin dependent diabetes mellitus. In the case of insulin resistance, it is believed that the IGF-I molecule which is structurally similar to that of insulin can block the action of the insulin receptor. Administration of rIGF-I to patients with type 2 diabetes, resulted in a 3.4-fold improvement in insulin sensitivity ${ }^{41}$. Whether diabetic patients receive insulin or oral hypoglycemic agents, it means that the glycemic level can be improved substantially by rIGF-I injections. In these patients, it is believed that IGF-I acts through facilitation of glucose utilization by peripheral tissues and also by increased insulin secretion from the pancreatic $\beta$-cells. Patients with mutations in the insulin-receptor gene or in genes related to the signal-transduction pathways, have different phenotypes including lipoatrophy syndrome or type A insulin resistance with mutations of the insulin-receptor gene, pseudoacromegaloidism, leprechaunism, and the RabsonMendenhall syndrome ${ }^{42}$.

Both clinical trials and everyday practice have confirmed that $\mathrm{rhGH} / \mathrm{rIGF}-\mathrm{I}$ positively effects body composition. It reduces the abdominal circumference as well as the amount of visceral fat ${ }^{43}$. It is important to highlight that rhGH is not approved for obesity treatment. Nevertheless, it can be reasonably assumed that rhGH, IGF-I or their analogues (tesamorelin) could help to effectively intervene in the metabolic process in obese patients ${ }^{44,45}$. 
In catabolic patients, anabolic hormone treatment results in improved whole body protein balance but use of rhGH and IGF-I treatment in critically ill patients is controversial. The Growth Hormone Research Society has recommended the cessation of rhGH (and by inference rIGF-I) use during critical illness ${ }^{46-49}$.

\section{Practical aspects of rIGF-I therapy}

The Food and Drug Administration (FDA) has approved clinical use of mecasermin, a recombinant human IGF-I analog intended for subcutaneous application ${ }^{50,51}$ and also of mecasermin rinfabate, a binary complex of equimolar IGF-I and IGFBP-3 (ref. ${ }^{52,53}$ ). However, only mecasermin is available in the Czech Republic. It is used for children $\geq 2$ years old and also for adolescents. The recommended initial dose is 0.04 to $0.08 \mathrm{mg} / \mathrm{kg}$ twice a day. If well-tolerated for a week, the dose can be increased by $0.04 \mathrm{mg} / \mathrm{kg}$ up to $0.12 \mathrm{mg} / \mathrm{kg}$ twice a day. The drug must be taken within 20 min after a meal. If the patient is unable to eat, rIGF-I should be omitted. If hypoglycemia occurs despite compliance with dietary regimen, the dose of mecasermin must be reduced. Mecasermin is not for intravenous use and is contraindicated in cases of hypersensitivity, after closure of the growth zones and in case of suspicion of an active neoplastic process. Initial enthusiasm for rIGF-I treatment vanished with the description of its numerous adverse effects. In addition to hypoglycemia, retinal edema, Bell's palsy, and severe myalgias have been reported. The frequency of these adverse effects can be usually reduced with $\mathrm{rIGF}-\mathrm{I}$ doses of $0.04 \mathrm{mg} / \mathrm{kg}$ twice a day only or less.

rIGF-I is not currently approved for the treatment of type 2 diabetes but it has been effectively used for blood glucose control in patients with rare extreme insulin resistance syndromes. Treatment with rIGF-I is also effective in patients with $\mathrm{GH}$ insensitivity due to $\mathrm{GH}$ receptor mutations and in patients of short stature and very low serum IGF-I (e.g., < 2.5 SDS) $\left(\right.$ ref. $\left.^{52}\right)$. Adverse effects, such as enhanced growth of tonsils, soft facial tissue, and kidneys, have been observed in some children. Currently, rIGF-I treatment is approved for children with short stature (<-3.0 SDS) or IGF-I level below -3.0 SDS but normal to elevated $\mathrm{GH}$ levels ${ }^{54}$.

\section{IGF-II}

IGF-II plays an important role in fetal and postnatal development. Not much is known about its physiological functions in adulthood. It is confirmed that tumor cells produce large amounts of IGF-II as a prohormone functioning in autocrine manner. High levels of IGF-II inhibit GH production. The low affinity of IGF-II to its binding proteins causes a high level of the free hormone which in turn results in suppression of glucose uptake by hepatocytes. This results in a tendency to hypoglycemia with preferential storage of glucose in myocytes. Removal of the tumor mass or radiation therapy are accompanied by normalization of IGF-II levels and restitution of normoglycemia. Rodent experiments have shown interesting possibilities for the use of IGF-II as a cognitive enhancing agent $^{55}$. However, there are many IGF-II functions yet to be elucidated. The clinical importance of such research is not entirely clear and strong motivation for it is lacking.

\section{ACKNOWLEDGEMENT}

Supported by grant IGA_LF-2015_015.

Author contributions: ZF: clinical setting; JS: genetics and laboratory techniques; MI: rIGF-I role; DK: literature search.

Conflict of interest statement: The authors declare that there are no conflicts of interest regarding the publication of this article.

\section{REFERENCES}

1. Salmon WD, Jr., Daughaday WH. A hormonally controlled serum factor which stimulates sulfate incorporation by cartilage in vitro. J Lab Clin Med 1957;49(6):825-36.

2. Rinderknecht $E$, Humbel RE. The amino acid sequence of human insulin-like growth factor I and its structural homology with proinsulin. J Biol Chem 1978;253(8):2769-76.

3. Han VK, D'Ercole AJ, Lund PK. Cellular localization of somatomedin (insulin-like growth factor) messenger RNA in the human fetus. Science 1987;236(4798):193-7.

4. Hoppener JW, de Pagter-Holthuizen P, Geurts van Kessel AH, Jansen M, Kittur SD, Antonarakis SE, Lips CJ, Sussenbach JS. The human gene encoding insulin-like growth factor I is located on chromosome 12. Hum Genet 1985;69(2):157-60.

5. Brissenden JE, Ullrich A, Francke U. Human chromosomal mapping of genes for insulin-like growth factors I and II and epidermal growth factor. Nature 1984;310(5980):781-4.

6. Di Bona D, Accardi G, Virruso C, Candore G, Caruso C. Association of Klotho polymorphisms with healthy aging: a systematic review and meta-analysis. Rejuvenation Res 2014;17(2):212-6.

7. Batey L, Moon JE, Yu Y, Wu B, Hirschhorn JN, Shen Y, Dauber A. A novel deletion of IGF1 in a patient with idiopathic short stature provides insight Into IGF1 haploinsufficiency. J Clin Endocrinol Metab 2014;99(1):E153-9.

8. Varela-Nieto I, Murillo-Cuesta S, Rodriguez-de la Rosa L, Lassatetta L, Contreras J. IGF-I deficiency and hearing loss: molecular clues and clinical implications. Pediatr Endocrinol Rev 2013;10(4):460-72.

9. Ziv E, Hu D. Genetic variation in insulin/IGF-1 signaling pathways and longevity. Ageing Res Rev 2011;10(2):201-4.

10. Cox OT, O'Shea S, Tresse E, Bustamante-Garrido M, Kiran-Deevi R, O'Connor R. IGF-1 Receptor and Adhesion Signaling: An Important Axis in Determining Cancer Cell Phenotype and Therapy Resistance. Front Endocrinol (Lausanne) 2015;6:106.

11. Janssen JA, Varewijck AJ. IGF-IR Targeted Therapy: Past, Present and Future. Front Endocrinol (Lausanne) 2014;5:224.

12. Troncoso R, Ibarra C, Vicencio JM, Jaimovich E, Lavandero S. New insights into IGF-1 signaling in the heart. Trends Endocrinol Metab 2014;25(3):128-37.

13. Di Bona D, Accardi G, Virruso C, Candore G, Caruso C. Association between genetic variations in the insulin/insulin-like growth factor (Igf-1) signaling pathway and longevity: a systematic review and meta-analysis. Curr Vasc Pharmacol 2014;12(5):674-81.

14. Walenkamp MJ, Losekoot M, Wit JM. Molecular IGF-1 and IGF-1 receptor defects: from genetics to clinical management. Endocr Dev 2013;24:128-37.

15. Succurro E, Andreozzi F, Marini MA, Lauro R, Hribal ML, Perticone F, Sesti G. Low plasma insulin-like growth factor-1 levels are associated with reduced insulin sensitivity and increased insulin secretion in nondiabetic subjects. Nutr Metab Cardiovasc Dis 2009;19(10):713-9.

16. Sandhu MS, Heald AH, Gibson JM, Cruickshank JK, Dunger DB, Wareham NJ. Circulating concentrations of insulin-like growth factor-I and development of glucose intolerance: a prospective observational study. Lancet 2002;359(9319):1740-5. 
17. Sandhu MS, Gibson JM, Heald AH, Dunger DB, Wareham NJ. Association between insulin-like growth factor-l: insulin-like growth factor-binding protein-1 ratio and metabolic and anthropometric factors in men and women. Cancer Epidemiol Biomarkers Prev 2004;13(1):166-70.

18. van Bunderen CC, van Nieuwpoort IC, van Schoor NM, Deeg DJ, Lips $\mathrm{P}$, Drent ML. The association of serum insulin-like growth factor-I with mortality, cardiovascular disease, and cancer in the elderly: a population-based study. J Clin Endocrinol Metab 2010;95(10):461624.

19. Misra M, Klibanski A. Endocrine consequences of anorexia nervosa. Lancet Diabetes Endocrinol 2014;2(7):581-92.

20. Clemmons DR. Metabolic actions of insulin-like growth factor-I in normal physiology and diabetes. Endocrinol Metab Clin North Am 2012;41(2):425-43, vii-viii.

21. Eddy KT, Lawson EA, Meade C, Meenaghan E, Horton SE, Misra M, Klibanski A, Miller KK. Appetite regulatory hormones in women with anorexia nervosa: binge-eating/purging versus restricting type. J Clin Psychiatry 2015;76(1):19-24.

22. Misra M, Miller KK, Herzog DB, Ramaswamy K, Aggarwal A, Almazan C, Neubauer G, Breu J, Klibanski A. Growth hormone and ghrelin responses to an oral glucose load in adolescent girls with anorexia nervosa and controls. J Clin Endocrinol Metab 2004;89(4):1605-12.

23. Guler HP, Zapf J, Schmid C, Froesch ER. Insulin-like growth factors and II in healthy man. Estimations of half-lives and production rates. Acta Endocrinol (Copenh) 1989;121(6):753-8.

24. Zapf J, Hauri C, Futo E, Hussain M, Rutishauser J, Maack CA, Froesch ER. Intravenously injected insulin-like growth factor (IGF) I/IGF binding protein-3 complex exerts insulin-like effects in hypophysectomized, but not in normal rats. J Clin Invest 1995;95(1):179-86.

25. Boisclair YR, Rhoads RP, Ueki I, Wang J, Ooi GT. The acid-labile subunit (ALS) of the $150 \mathrm{kDa}$ IGF-binding protein complex: an important but forgotten component of the circulating IGF system. J Endocrino 2001;170(1):63-70.

26. Domene HM, Hwa V, Jasper HG, Rosenfeld RG. Acid-labile subunit (ALS) deficiency. Best Pract Res Clin Endocrinol Metab 2011;25(1):101-13.

27. Ramadhin C, Pillay B, Olaniran AO. Cell-based assays for IGF-I bioactivity measurement: overview, limitations and current trends. Growth Factors 2014;32(3-4):130-8

28. Daughaday WH, Parker KA, Borowsky S, Trivedi B, Kapadia M Measurement of somatomedin-related peptides in fetal, neonatal, and maternal rat serum by insulin-like growth factor (IGF) I radioimmunoassay, IGF-II radioreceptor assay (RRA), and multiplicationstimulating activity RRA after acid-ethanol extraction. Endocrinology 1982;110(2):575-81.

29. Khosravi MJ, Diamandi A, Mistry J, Lee PD. Noncompetitive ELISA for human serum insulin-like growth factor-I. Clin Chem 1996;42(8 Pt 1):1147-54.

30. Melmed S, Colao A, Barkan A, Molitch M, Grossman AB, Kleinberg D, Clemmons D, Chanson P, Laws E, Schlechte J, Vance ML, Ho K Giustina A. Guidelines for acromegaly management: an update. J Clin Endocrinol Metab 2009;94(5):1509-17.

31. Bolanowski M, Ruchala M, Zgliczynski W, Kos-Kudla B, BaldysWaligorska A, Zielinski G, Bednarczuk T, Hubalewska-Dydejczyk A, Kaminski G, Marek B, Daroszewski J, Wasko R, Lewinski A. Acromegaly--a novel view of the patient. Polish proposals for diagnostic and therapeutic procedures in the light of recent reports. Endokrynol Pol 2014;65(4):326-31.

32. Cap J, Cerman J, Nemecek S, Marekova M, Hana V, Frysak Z. The influence of treatment with somatostatin analogues on morphology, proliferative and apoptotic activity in $\mathrm{GH}$-secreting pituitary adenomas. J Clin Neurosci 2003;10(4):444-8.

33. Caron PJ, Bevan JS, Petersenn S, Flanagan D, Tabarin A, Prevost G, Maisonobe $\mathrm{P}, \mathrm{Clermont} \mathrm{A}$. Tumor shrinkage with lanreotide Autogel $120 \mathrm{mg}$ as primary therapy in acromegaly: results of a prospective multicenter clinical trial. J Clin Endocrinol Metab 2014;99(4):1282-90.

34. Lebl J, Zapletalova J. Léčba růstovým hormonem v pediatrii. Historie a současnost. Klin Farmakol 2011;25(1):18-23.

35. Ho KK. Consensus guidelines for the diagnosis and treatment of adults with GH deficiency II: a statement of the GH Research Society in association with the European Society for Pediatric Endocrinology, Lawson Wilkins Society, European Society of Endocrinology,
Japan Endocrine Society, and Endocrine Society of Australia. Eur J Endocrinol 2007;157(6):695-700.

36. Newman CB, Carmichael JD, Kleinberg DL. Effects of low dose versus high dose human growth hormone on body composition and lipids in adults with GH deficiency: a meta-analysis of placebo-controlled randomized trials. Pituitary 2015;18(3):297-305.

37. Khwaja OS, Ho E, Barnes KV, O'Leary HM, Pereira LM, Finkelstein Y, Nelson CA, 3rd, Vogel-Farley V, DeGregorio G, Holm IA, Khatwa U, Kapur K, Alexander ME, Finnegan DM, Cantwell NG, Walco AC, Rappaport L, Gregas M, Fichorova RN, Shannon MW, Sur M, Kaufmann WE. Safety, pharmacokinetics, and preliminary assessment of efficacy of mecasermin (recombinant human IGF1) for the treatment of Rett syndrome. Proc Natl Acad Sci U S A 2014;111(12):4596-601.

38. Laron Z. Laron syndrome (primary growth hormone resistance or insensitivity): the personal experience 1958-2003. J Clin Endocrinol Metab 2004;89(3):1031-44.

39. Laron Z, Pertzelan A, Mannheimer S. Genetic pituitary dwarfism with high serum concentation of growth hormone--a new inborn error of metabolism? Isr J Med Sci 1966;2(2):152-5.

40. Kronenberg HM, Melmed S, Larsen PR, Polonsky KS. CHAPTER 1 - Principles of Endocrinology. In: Kronenberg SMSPRLM, editor. Williams Textbook of Endocrinology (Twelfth Edition). Philadelphia: Content Repository Only!; 2011. p. 3-12.

41. Woods KA, Camacho-Hubner C, Bergman RN, Barter D, Clark AJ Savage MO. Effects of insulin-like growth factor I (IGF-I) therapy on body composition and insulin resistance in IGF-I gene deletion. J Clin Endocrinol Metab 2000;85(4):1407-11.

42. Ros P, Colino-Alcol E, Grasso V, Barbetti F, Argente J. [Severe type A insulin resistance syndrome due to a mutation in the insulin receptor gene]. An Pediatr (Barc) 2015;82(1):e30-4

43. Berryman DE, Glad CA, List EO, Johannsson G. The GH/IGF-1 axis in obesity: pathophysiology and therapeutic considerations. Nat Rev Endocrinol 2013;9(6):346-56

44. Makimura H, Feldpausch MN, Rope AM, Hemphill LC, Torriani M, Lee $H$, Grinspoon SK. Metabolic effects of a growth hormonereleasing factor in obese subjects with reduced growth hormone secretion: a randomized controlled trial. J Clin Endocrinol Metab 2012;97(12):4769-79.

45. Makimura H, Murphy CA, Feldpausch MN, Grinspoon SK. The effects of tesamorelin on phosphocreatine recovery in obese subjects with reduced GH. J Clin Endocrinol Metab 2014;99(1):338-43.

46. Yarwood GD, Ross RJ, Medbak S, Coakley J, Hinds CJ. Administration of human recombinant insulin-like growth factor-l in critically ill patients. Crit Care Med 1997;25(8):1352-61.

47. Hajsadeghi S, Khamseh ME, Gholami S, Kerman SR, Gohardehi G, Moghadam NS, Sabet AS, Moradi M, Mollahoseini R, Najafi M, Keramati MR. IGF-I concentration and changes in critically ill patients. J Res Med Sci 2011;16(2):170-8.

48. Elijah IE, Branski LK, Finnerty CC, Herndon DN. The GH/IGF-1 system in critical illness. Best Pract Res Clin Endocrinol Metab 2011;25(5):759-67.

49. Teng Chung T, Hinds CJ. Treatment with GH and IGF-1 in critical illness. Crit Care Clin 2006;22(1):29-40, vi.

50. Latrech H, Simon A, Beltrand J, Souberbielle JC, Belmejdoub G, Polak M. Postprandial hyperglycemia corrected by IGF-I (Increlex(R)) in Laron syndrome. Horm Res Paediatr 2012;78(3):193-200.

51. Kemp SF. Mecasermin rinfabate. Drugs Today (Barc) 2007;43(3):14955.

52. Kemp SF. Insulin-like growth factor-I deficiency in children with growth hormone insensitivity: current and future treatment options. BioDrugs 2009;23(3):155-63.

53. Kemp SF, Fowlkes JL, Thrailkill KM. Efficacy and safety of mecasermin rinfabate. Expert Opin Biol Ther 2006;6(5):533-8.

54. Fintini D, Brufani C, Cappa M. Profile of mecasermin for the long-term treatment of growth failure in children and adolescents with severe primary IGF-1 deficiency. Ther Clin Risk Manag 2009;5(3):553-9.

55. Chen DY, Stern SA, Garcia-Osta A, Saunier-Rebori B, Pollonini G, Bambah-Mukku D, Blitzer RD, Alberini CM. A critical role for IGF-II in memory consolidation and enhancement. Nature 2011:469(7331):491-7. 